\title{
Usage of Fusible Sewing Threads to Improve the Waterproof Property of Seams
}

\author{
Cansu MESEGUL ${ }^{1}$, Gulseren KARABAY ${ }^{2 *}$ \\ ${ }^{1}$ Dokuz Eylul University Graduate School of Natural and Applied Sciences, Turkey \\ ${ }^{2}$ Dokuz Eylul University Textile Engineering Department, Turkey \\ crossref http://dx.doi.org/10.5755/j01.ms.26.4.24147
}

Received 11 September 2019; accepted 25 November 2019

\begin{abstract}
In classical stitching process, needle holes occur during the penetration of the needle through the fabric. If the waterproofness of the sewn product is important, the water leakage from these holes must be prevented. To prevent this negative situation, different techniques such as sealing of seams with waterproof tapes, joining the textile materials by bonding or welding are used. Among these techniques, there is no needle damage in bonding and welding and all the seam area is covered by thermal or chemical bonding. In sewing technology, the water leakage is prevented by covering all the seam area with seam sealing tape. These three methods have different effects on the physical properties of the seams obtained. Instead of covering the whole seam area, covering just the needle damages is the focus of this research. With this aim, fusible sewing threads were used to cover the needle damages to increase the waterproof performance of seam line. The fusible sewing threads have not been used for obtaining waterproof seams before. In this research, the fusible sewing threads were used as lower thread in different combinations. Initial results of waterproofness test show that, melted fusible threads improve the waterproof performance of seams. In other words, the needle damages on sewn fabric can be covered by melted fusible sewing thread. However, unbalanced seam is the negative side of this research because of using different threads as needle and bobbin thread. Additionally, there is no variety of fusible threads to select an appropriate one for this method. The study is hoped to be a sample for the further studies on this method, using different fusible threads, fabrics, seam types and even improving new fusible threads for this waterproofing method.

Keywords: waterproof, stitching, seam, fusible sewing thread, sealing, coated fabric, needle damage.
\end{abstract}

\section{INTRODUCTION}

Sewing is the mostly used joining process for making a garment; however, it causes damages due to needles along the seam line. It is important to understand the damage during sewing operations as it is crucial when the sewn fabric has waterproof property. The needle holes cause leakage of water. To prevent this problem, seam sealing, welding and bonding techniques may be used according to the application area of waterproof fabric.

The seamed fabrics are sealed by waterproof sealing tape to prevent water from penetrating through the holes caused by the needle during sewing [1]. Sealing has been widely used in outdoor garments, however, there are quality problems resulted from needle holes and thread such as seam leaking and excess shrinkage [2]. The clothing sealed by waterproofing tape produces somewhat discomfort feeling regardless of seam direction [3]. Besides, sealing tapes affect the draping and bending resistance of the fabric. Therefore, changes in the mechanical performances from sewing and sealing processes should be considered for high production efficiency with the most suitable functional quality [3].

The other method of joining of the textile structures is welding. Welding is thermal bonding and sealing of thermoplastic materials [4]. Availability of this method depends on the thermoplastic content of the material to be joined. A minimum of $65 \%$ of thermoplastic content enables the joining of textile materials under pressure [5]. Welded seams may give waterproof seams, but the fabric

\footnotetext{
* Corresponding author. Tel.: +90-2323017713; fax: +90-2323017750. E-mail address: gulseren.karabay@deu.edu.tr (G. Karabay)
}

strength can be reduced by as much as $60 \%$ and the seam strength may be as little as $50 \%$ of a sewn seam [6]. Also, due to the thickness of the fabric layers, though the construction of the seams are possible, some lapped seams are not successful in terms of quality. The bound seam type and the flat seams are possible using ultrasonic technology without the blade but the quality is not satisfactory when comparing to the conventional sewing technique [7].

During application of bonding technique, different from the welding, chemicals or liquid glue is used in order to join the materials [4].

Both in welding and bonding technique, there is no need to use an external seam tape as there is no needle damage through the seamline [8].

There are some studies examining the performance of waterproof fabrics from different point of views.

Jana reviewed [4] the distinguished characteristics and developments in assembling technologies, such as sewing, welding and bonding along with the challenges ahead in this area. The paper stated that there is a distinct shift towards use of welding and bonding technologies in functional clothing because of the reduced bulk and weight, cleaner appearance and sealing qualities offered by these seams.

Jakubčionienè and et. al. [9] investigated the strength of textile bonded seams using four different bond types, in order to determine method suitable for analyzes of bonded seams of knitted fabrics and method suitable to analyze woven fabrics.

Grineviciute and et. al. [10] examined seam strength in longitudinal and cross direction and resistance to water 
penetration were determined for investigation of quality of sealed seams with thermoplastic polyurethane tape. They determined the efficiency of sealed seams, optimal sealing parameters (temperature, sealing speed and quill pressure) for obtaining a good seam performance.

Shi [2] used combination of ultrasonic welding-thermo adhesive tape sealing in order to improve the waterproof performance of seam.

Vlad and et. al. [11] examined the influence of the sealing parameters on the resistance of specific assemblies for clothing products made of waterproof materials. They determined the optimum sealing parameters namely temperature, work speed, the pressure of the roller and of the air for double and triple laminated materials.

Korycki and Szafrańska [12] determined the optimal thickness of material layers in seams in respect of their insulating properties. They analysed the insulation of different types of sealed seams which are typically used to connect the different parts of clothing.

Eryuruk and et. al. [13] examined the effects of ultrasonic welding parameters on bond strength, seam thickness and seam stiffness, as well as water permeability.

Radhakrishnan and Kumari [14] reviewed the serged seams, hot sealed seams and bonded seams, which are used for protective clothing, based on the end use.

In these studies, generally the seam performance, mechanical properties of sealed or bonded part were investigated. In this research, apart from these studies, an alternative method was presented to examine using fusible sewing threads as lower threads in lockstitch. These yarns can be used for stabilization of raschel laces, ribbons, picot edges for underwear, edges for seamless, fully-fashioned and compression hosiery and hems, separation yarns for knitted textiles, fixation of cutting edges for labels, improvement of mechanical properties of textile fabrics [15]. Fusible threads have not been used for obtaining waterproof seams before. Low melting fusible yarns are available in various melting points and counts and they can be stitched, knitted or woven. It is thus possible to use them precisely and effectively where needed. These yarns are made out of low melt fusible yarn twisted with normal melting point polyamid and polyester carrier thread [16]. By selecting and combining the proper raw material ratios, melting points between $60{ }^{\circ} \mathrm{C}$ and $150{ }^{\circ} \mathrm{C}$ are possible and they may have excellent resistance to laundering and drycleaning [15]. In current seam sealing method, all the seamline is covered with a waterproof sealing tape and this affects the physical properties of the fabric at that seam area. In this paper, the fusible threads were used to cover the space, which remained after filling of the needle holes with sewing thread, in order to prevent the leakage of water through this space. The aim of using this fusible sewing thread was to cover just the needle holes instead of the whole seamline area to improve the waterproofness of seam line.

\section{MATERIALS AND METHOD}

To achieve the purpose of the research, waterproofcoated fabrics were selected as experimental materials. The properties of coated fabrics used are given in Table 1. Two different test fabrics, having similar structural properties but carrying different amount of coating materials, were used to examine the needle damages due to sewing process.

Table 1. Properties of the fabrics used in experiment

\begin{tabular}{|c|c|c|c|c|c|c|c|}
\hline \multirow[b]{2}{*}{$\begin{array}{l}\text { Fabric } \\
\text { code }\end{array}$} & \multirow{2}{*}{$\begin{array}{l}\text { Fabric } \\
\text { composition } \\
\text { and weave }\end{array}$} & \multicolumn{2}{|c|}{ Fabric Density } & \multicolumn{2}{|c|}{$\begin{array}{l}\text { Fabric unit } \\
\text { weight }\left(\mathrm{g} / \mathrm{m}^{2}\right)\end{array}$} & \multirow{2}{*}{$\begin{array}{l}\text { Weight } \\
\text { change } \\
\text { after } \\
\text { coating } \\
\text { process, \% } \\
((\mathrm{b}- \\
\mathrm{a} / \mathrm{a}) * 100\end{array}$} & \multirow[b]{2}{*}{$\begin{array}{c}\text { Thickness } \\
\mathrm{mm}\end{array}$} \\
\hline & & $\begin{array}{l}\text { Weft, } \\
\text { picks } \\
\text { per cm }\end{array}$ & $\begin{array}{l}\text { Warp, } \\
\text { ends } \\
\text { per cm }\end{array}$ & $\begin{array}{l}\text { Base } \\
\text { fabric } \\
\text { (a) }\end{array}$ & $\begin{array}{c}\text { Coated } \\
\text { fabric } \\
\text { (b) }\end{array}$ & & \\
\hline A & $\begin{array}{c}100 \% \mathrm{PA} / \\
\text { Plain weave }\end{array}$ & 12 & 13 & 297.5 & 470.6 & 58.2 & 0.53 \\
\hline B & $\begin{array}{c}100 \% \text { PA/ } \\
\text { Plain weave }\end{array}$ & 12 & 13 & 282.1 & 365.1 & 29.4 & 0.51 \\
\hline
\end{tabular}

The coated fabrics were manufactured on Monforts Stork coating line with knife coating method. Fluorocarbon was used as coating material. The test fabrics were sewn by using the combinations of four different sewing threads, two of which were antiwick and two of which were fusible, as the lower thread (Table 2).

Table 2. Properties of sewing threads

\begin{tabular}{|l|l|c|}
\hline $\begin{array}{c}\text { Sewing } \\
\text { thread }\end{array}$ & \multicolumn{1}{|c|}{ Thread composition } & $\begin{array}{c}\text { Thread lineer } \\
\text { density, tex }\end{array}$ \\
\hline ST80 & Polyester / Cotton & 80 \\
\hline ST150 & Polyester / Cotton & 150 \\
\hline ST135 & $\begin{array}{l}85 \% \text { low melt co-polyamide and } \\
15 \% \text { polyester }(\text { Co-polyamide part } \\
\left.\text { melts between } 100-110^{\circ} \mathrm{C}\right)\end{array}$ & 135 \\
\hline ST40 & $\begin{array}{l}\text { Co-polyamide filament }(\mathrm{Co}- \\
\text { polyamide melts between } \\
\left.100-110^{\circ} \mathrm{C}\right)\end{array}$ & 40 \\
\hline
\end{tabular}

The reason of selecting these PES/Co antiwick corespun sewing threads, having different linear densities, is to compare coverage of needle damages with different lower thread combination. Fig. 1 shows the images of the threads taken with a stereomicroscope (Olympus SZ61, Japan).

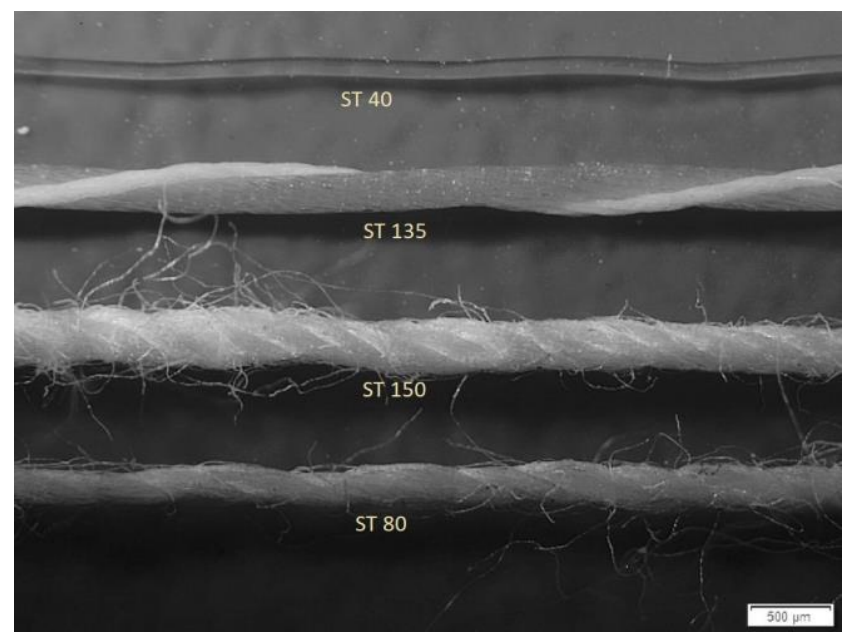

Fig. 1. Images of Sewing Threads (X6.7)

In this research, ST 80 sewing thread was used in upper thread position in all samples. The fusible sewing threads could be only used in lower thread combinations, as two separate upper threads would cause a technical problem in loop formation and capturing stage, which is a 
fundamental step in stitching. Therefore, the threads were wound together with corespun sewing threads in different lower thread combinations to the shuttle. The lower thread combinations in samples are ST80, ST150, ST80+ST40, ST150+ST40, ST135, ST80+ST135 respectively.

Five test fabrics, cut in $25 \mathrm{~cm} \times 25 \mathrm{~cm}$ dimensions, were prepared for each type of samples. According to ASTM D1683, Nm 120(19) needle and Tex 80 sewing thread are recommended for woven fabrics with $270-405 \mathrm{~g} / \mathrm{m}^{2}$ unit weight. In order to give less damage to the fabric, Nm 90(14) size, slim set point (SPI) type of sewing needle was preferred for sewing the samples. Slim Set Point (SPI), is used for heavy woven fabrics and coated fabrics as it causes less damage. All the fabrics were sewn with lockstitch from the middle of two edges of samples with 3 stitches/cm stitch density according to the defined thread combinations. In addition, in order to inspect the needle damage, needle holes were formed in the fabric by sewing without any thread on lockstitch machine. In other words, the fabrics were perforated by stitching without thread with the lockstitch machine. After the sewing process, the samples, having fusible threads, were ironed by considering the ironing instructions of sewing thread company. The procedure for melting co-polyamide is to iron the seam between $100-110{ }^{\circ} \mathrm{C}$ for 10 seconds. To see the behaviors of fusible sewing threads against heat the digital images were taken by the camera on stereomicroscope with X6.7, X8 and X25 magnificence before and after ironing process. Besides, the needle damages on sewn area of fabrics were viewed.

Afterwards, all test samples were tested for the evaluation of the waterproofness performance of sewn areas of samples. The waterproofness tests were conducted by using a Textest FX 3000 Hydrostatic Head Tester III according to ISO 811:2018 standard. Pressure gradient was $60 \mathrm{~cm} / \mathrm{min}$ and the testing area was $100 \mathrm{~cm}^{2}$. The pressure of the first and the third water drops were recorded and five repetitions were done for each test sample. The waterproofness results of fabric A and B were not compared with each other, as the same coating process was not applied to the fabrics. The waterproofness of the samples was compared around each other in their own

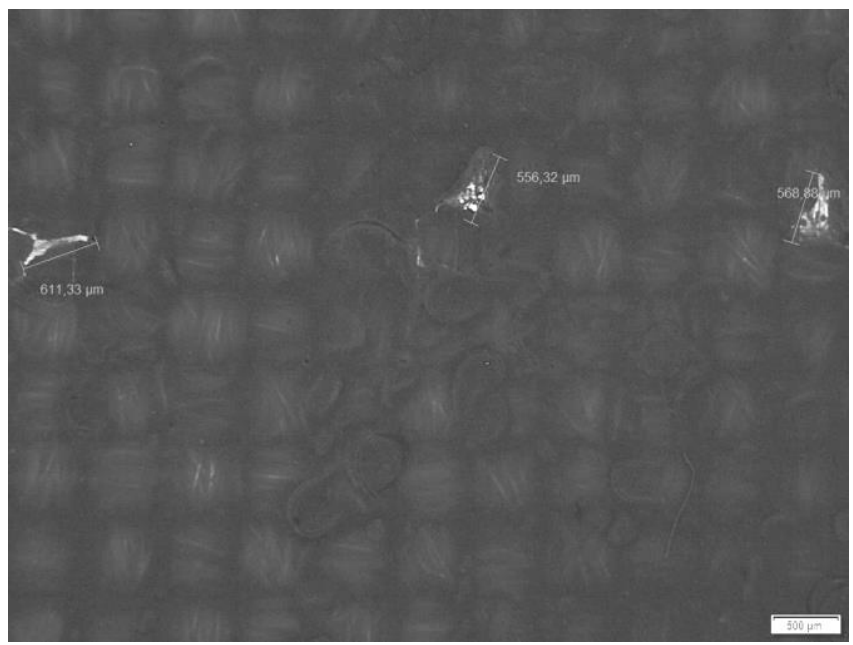

a fabric type. Waterproofness test results were evaluated statistically with the help of variance analysis. Statistical analysis was made by using IBM SPSS Statistics 24 program at a $95 \%$ significance level. Before comparing the waterproofness test results of the sewn samples, normality test of Kolmogorov-Smirnov and Levene statistic for homogeneity were applied to the waterproofness data of both fabric types. The waterproofness of samples was compared on each fabric types own merit.

\section{RESULTS}

\subsection{Stereomicroscopic examining of materials}

The task of the tip of the sewing needle is to make a hole for the pass of the sewing thread whether by pushing the fabric threads (warp or weft) or cutting them. The images of needle damages on perforated samples of fabric $\mathrm{A}$ and $\mathrm{B}$ are seen in Fig. $2 \mathrm{a}$ and $\mathrm{b}$ respectively.

The torn areas around the needle damage are observed clearly on fabric A, in Fig. 2 a. The dimensions of the needle damages were measured as $611.33 \mu \mathrm{m}, 556.32 \mu \mathrm{m}$ and $568.88 \mu \mathrm{m}$ under stereomicroscope with $\mathrm{X} 8$ magnification. The needle holes on fabric $\mathrm{B}$ have more elliptical shapes. The dimensions of the needle damages were measured as $360.68 \mu \mathrm{m}, 422.59 \mu \mathrm{m}$ and $365.30 \mu \mathrm{m}$ at X8 magnification. The melted fusible threads (ST40 and ST135) flatten and spread over the needle holes through the seam line as seen in Fig. $3 \mathrm{a}$ and $\mathrm{b}$ at magnificence $\mathrm{X} 25$. Thus, the needle damages are covered slightly. Intersection point of upper and lower sewing threads of seam covers these needle holes (needle damage) as much as their area. The other important point is the unbalanced seam due to using different upper and lower thread types in seams as seen in Fig. $3 a$ and b. In lockstitch sewing, the needle and bobbin threads should interact in the middle of the assembly, which is indicated by equal consumption of the needle and bobbin threads [17]. During lockstitch formation, the needle thread pulls the bobbin thread into the fabric.

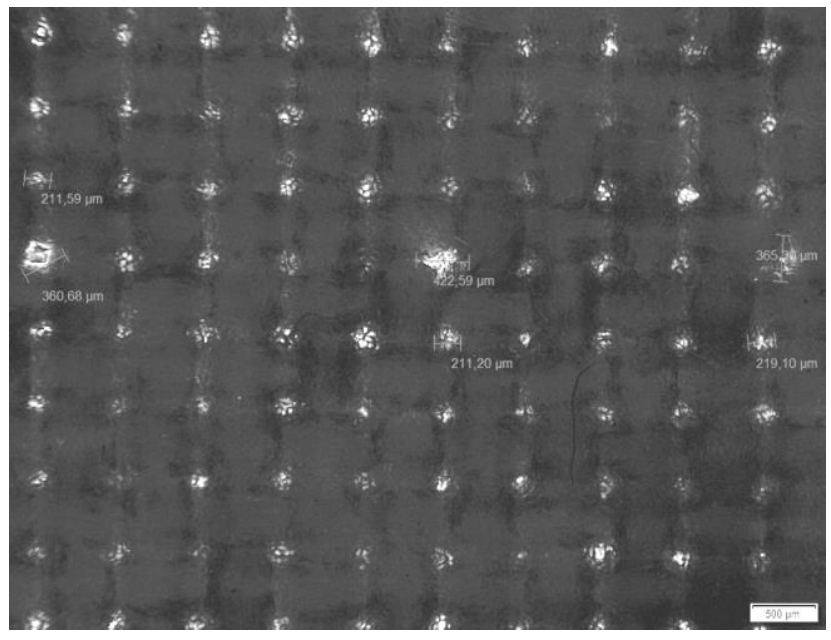

b

Fig. 2. Needle damages images from the backsides: $a$-fabric A; b-fabric B (X8) 


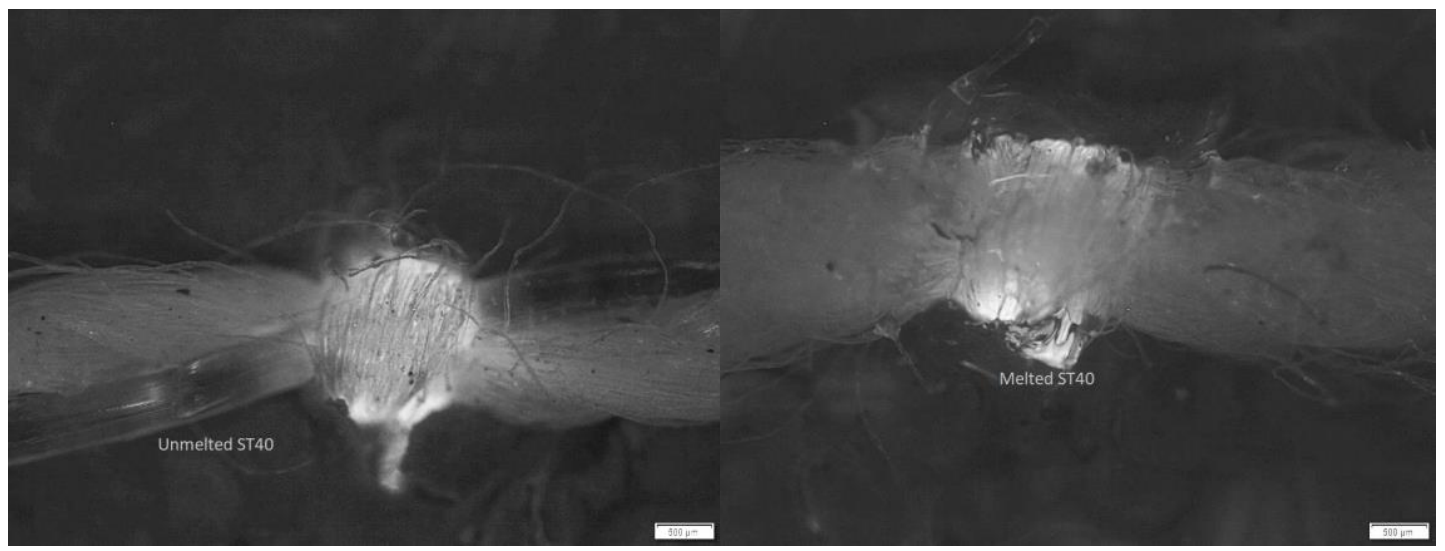

a

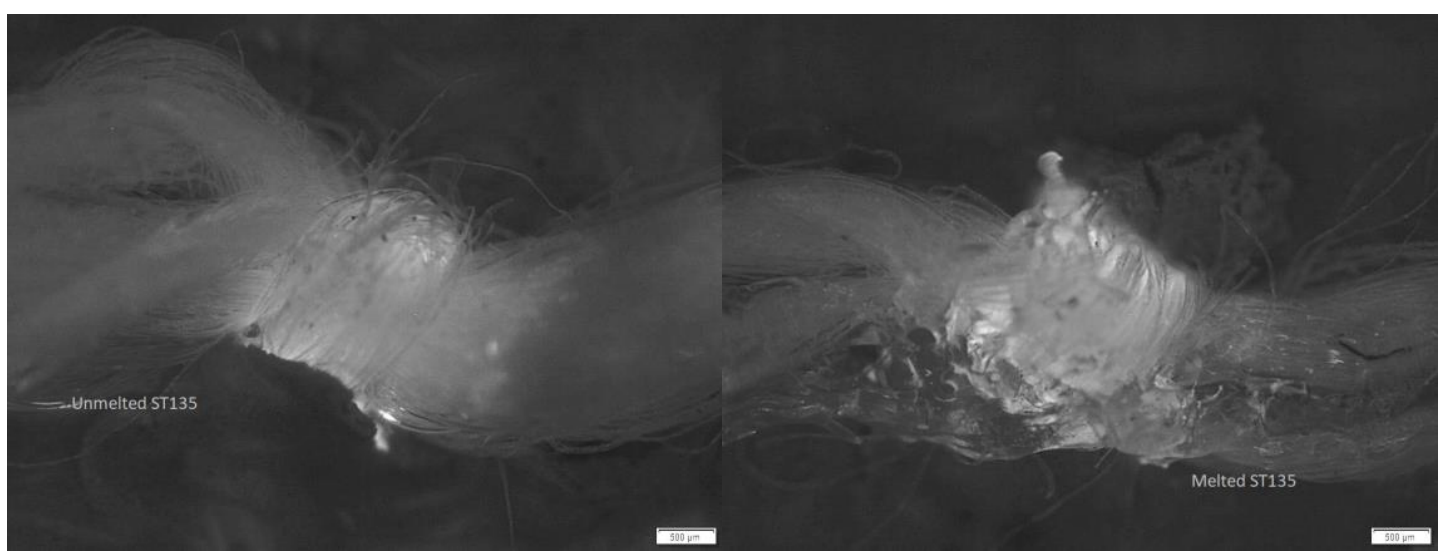

b

Fig. 3. Unmelted and melted forms of sewing threads: a-ST40; b-ST135

This situation is not considered in this preliminary research of getting waterproof seams by using fusible threads.

\subsection{Waterproofness test results}

Regardless of the waterproofness performance of the used fabrics, the stitching process makes the seam line be the weakest area on the sewn fabric. The greater the needle damage on the seam line, the lower the waterproofness performance is. After the sewing process, the sewing thread covers the needle hole as far as its footprint. In this research, the waterproofness value of the seam, which is made with ST80/ST80 upper and lower tread combination (sample 1), is accepted the reference value for comparison of the waterproof performances of other seam combinations. Table 3 shows the five repetitive waterproofness test results of unstitched, perforated and sewn samples of Fabrics A and B.

For fabric A, the waterproofness data have a normal distribution as sig values are over 0.05 . It was homogeny as the Levene statistic was 0.389. One-way ANOVA was applied to the waterproofness results. Sig value of the ANOVA test was 0.000 . Therefore, Tukey statistics was used to see which lower thread combinations (samples) have significant differences between each other. The multiple comparisons of waterproofness results of samples are given in Table 4 . The differences between the mean waterproofness values of sample 1 (reference seam ST80/ST80) and the other samples are significant according to Table 4. For Fabric A, it can be said that as the lower thread combination thickens (linear density), the waterproofness of the seam increases to a certain extent. In addition, the fusible threads, ST 40 and ST 135, contribute to the waterproofness performance of seams. However, the samples 5 and 6, which contain ST 135 in their lower thread combination, show better waterproofness results when they are compared with the samples 2 and 4 , which have thicker lower thread combinations.

Thus, it can be thought that melted ST 135 thread helps to cover the needle damage more effectively.

The waterproofness data of fabric $\mathrm{B}$ have a normal distribution as sig values are over 0.05. It was not homogeny as the Levene statistic was 0.033 .

One way ANOVA was applied to the waterproofness results. Sig value of the ANOVA test was 0.000 . Therefore, Tamhane statistics was used to see which lower thread combinations (samples) have significant differences between each other. The multiple comparisons of waterproofness results of samples are given in Table 5. In Table 5, sample 1 has the least mean waterproofness value among the other samples.

As the needle damages on the samples 2,3,4,5,6 are covered much more, the samples 2,3,4,5 and 6 have significantly higher mean waterproofness values compared to sample 1 at $5 \%$ significance level. 
Table 3. Waterproofness test results of unstitched, perforated and stitched forms of Fabrics A and B

\begin{tabular}{|c|c|c|c|c|c|c|c|}
\hline \multicolumn{8}{|c|}{ Fabric A } \\
\hline Unstitched fabric & $\begin{array}{c}\text { Perforated } \\
\text { fabric } \\
\text { (threadless) }\end{array}$ & $\begin{array}{l}\text { Sample 1: } \\
\text { ST80/ST80 }\end{array}$ & $\begin{array}{c}\text { Sample 2: } \\
\text { ST80/ST150 }\end{array}$ & $\begin{array}{c}\text { Sample 3: } \\
\text { ST80/ST80+ST40 }\end{array}$ & $\begin{array}{c}\text { Sample 4: } \\
\text { ST80/ST150+ST40 }\end{array}$ & $\begin{array}{c}\text { Sample 5: } \\
\text { ST80/ST135 }\end{array}$ & $\begin{array}{c}\text { Sample 6: } \\
\text { ST80/ST80+ ST135 }\end{array}$ \\
\hline 613 & 171 & 224 & 213 & 203 & 222 & 226 & 260 \\
\hline 622 & 182 & 216 & 220 & 188 & 218 & 254 & 245 \\
\hline 508 & 176 & 215 & 193 & 212 & 232 & 237 & 247 \\
\hline 608 & 164 & 218 & 221 & 218 & 220 & 241 & 236 \\
\hline 506 & 178 & 204 & 201 & 197 & 214 & 233 & 242 \\
\hline \multicolumn{8}{|c|}{ Fabric B } \\
\hline Unstitched fabric & $\begin{array}{c}\text { Perforated } \\
\text { fabric } \\
\text { (threadless) }\end{array}$ & $\begin{array}{l}\text { Sample 1: } \\
\text { ST80/ST80 }\end{array}$ & $\begin{array}{c}\text { Sample 2: } \\
\text { ST80/ST150 }\end{array}$ & $\begin{array}{c}\text { Sample 3: } \\
\text { ST80/ST80+ST40 }\end{array}$ & $\begin{array}{c}\text { Sample 4: } \\
\text { ST80/ST150+ST40 }\end{array}$ & $\begin{array}{c}\text { Sample 5: } \\
\text { ST80/ST135 }\end{array}$ & $\begin{array}{c}\text { Sample 6: } \\
\text { ST80/ST80+ST135 }\end{array}$ \\
\hline 1580 & 206 & 225 & 245 & 272 & 270 & 274 & 283 \\
\hline 1663 & 185 & 231 & 283 & 284 & 266 & 271 & 287 \\
\hline 1687 & 184 & 232 & 272 & 267 & 263 & 304 & 307 \\
\hline 1607 & 180 & 218 & 254 & 262 & 256 & 297 & 322 \\
\hline 1580 & 191 & 225 & 269 & 257 & 245 & 317 & 274 \\
\hline
\end{tabular}

Table 4. Multiple comparisons of waterproofness of stitched area on Fabric A (Tukey test)

\begin{tabular}{|c|c|c|c|c|}
\hline Code number of combination & Lower thread combinations (a) & $\begin{array}{c}\text { Lower thread } \\
\text { combinations (b) }\end{array}$ & Mean difference $(a-b)$ & Sig. \\
\hline \multirow{5}{*}{ Sample 1} & \multirow{5}{*}{ ST80/ST80 } & ST80/ST150 & $-34.0^{*}$ & 0.000 \\
\hline & & ST80/ST80+ST40 & $-28.0^{*}$ & 0.001 \\
\hline & & ST80/ST150+ST40 & $-45.6^{*}$ & 0.000 \\
\hline & & ST80/ST135 & $-62.6^{*}$ & 0.000 \\
\hline & & ST80/ST80+ST135 & $-70.4^{*}$ & 0.000 \\
\hline \multirow{5}{*}{ Sample 2} & \multirow{5}{*}{ ST80/ST150 } & ST80/ST80 & $34.0 *$ & 0.000 \\
\hline & & ST80/ST80+ST40 & 6.0 & 0.916 \\
\hline & & ST80/ST150+ST40 & -11.6 & 0.416 \\
\hline & & ST80/ST135 & $-28.6^{*}$ & 0.001 \\
\hline & & ST80/ST80+ST135 & $-36.4^{*}$ & 0.000 \\
\hline \multirow{5}{*}{ Sample 3} & \multirow{5}{*}{ ST80/ST80+ST40 } & ST80/ST80 & $28.0^{*}$ & 0.001 \\
\hline & & ST80/ST150 & -6.0 & 0.916 \\
\hline & & ST80/ST150+ST40 & -17.6 & 0.073 \\
\hline & & ST80/ST135 & $-34.6^{*}$ & 0.000 \\
\hline & & ST80/ST80+ST135 & $-42.4^{*}$ & 0.000 \\
\hline \multirow{5}{*}{ Sample 4} & \multirow{5}{*}{ ST80/ST150+ST40 } & ST80/ST80 & $45.6^{*}$ & 0.000 \\
\hline & & ST80/ST150 & 11.6 & 0.416 \\
\hline & & ST80/ST80+ST40 & 17.6 & 0.073 \\
\hline & & ST80/ST135 & -17.0 & 0.090 \\
\hline & & ST80/ST80+ST135 & $-24.8^{*}$ & 0.005 \\
\hline \multirow{5}{*}{ Sample 5} & \multirow{5}{*}{ ST80/ST135 } & ST80/ST80 & $62.6^{*}$ & 0.000 \\
\hline & & ST80/ST150 & $28.6^{*}$ & 0.001 \\
\hline & & ST80/ST80+ST40 & $34.6^{*}$ & 0.000 \\
\hline & & ST80/ST150+ST40 & 17.0 & 0.090 \\
\hline & & ST80/ST80+ST135 & -7.8 & 0.787 \\
\hline \multirow{5}{*}{ Sample 6} & \multirow{5}{*}{ ST80/ST80+ST135 } & ST80/ST80 & $70.4^{*}$ & 0.000 \\
\hline & & ST80/ST150 & $36.4^{*}$ & 0.000 \\
\hline & & ST80/ST80+ST40 & 42.4 & 0.000 \\
\hline & & ST80/ST150+ST40 & $24.8^{*}$ & 0.005 \\
\hline & & ST80/ST135 & 7.8 & 0.787 \\
\hline
\end{tabular}

However, the differences among the waterproofness values of the samples 2,3,4,5,6 are not important at $95 \%$ significance level. For Fabric B, the waterproofness value of the samples did not increase as the thickness of the lower thread combination of seams increased. It is thought that as the needle damages on the fabric B have more even shapes compared to the Fabric A's, even ST 40 made a significant contribution to sample 3's waterproofness value at $95 \%$ significance level. ST40 and ST135 seem to contribute to the waterproofing values of the seams. 
Table 5. Multiple comparisons of waterproofness of stitched area on Fabric B (Tamhane Test)

\begin{tabular}{|c|c|c|c|c|}
\hline $\begin{array}{l}\text { Code number of } \\
\text { combination }\end{array}$ & $\begin{array}{l}\text { Upper/Lower thread } \\
\text { combinations (a) }\end{array}$ & Thread combinations (b) & Mean difference $(a-b)$ & Sig. \\
\hline \multirow{5}{*}{ Sample 1} & \multirow{5}{*}{ ST80/ST80 } & ST80/ST150 & $-38.4^{*}$ & 0.043 \\
\hline & & ST80/ST80+ST40 & $-42.2^{*}$ & 0.003 \\
\hline & & ST80/ST150+ST40 & $-33.8^{*}$ & 0.006 \\
\hline & & ST80/ST135 & $-66.4^{*}$ & 0.016 \\
\hline & & ST80/ST80+ST135 & $-68.4^{*}$ & 0.013 \\
\hline \multirow{5}{*}{ Sample 2} & \multirow{5}{*}{ ST80/ST150 } & ST80/ST80 & $38.4^{*}$ & 0.043 \\
\hline & & ST80/ST80+ST40 & -3.8 & 1.000 \\
\hline & & ST80/ST150+ST40 & 4.6 & 1.000 \\
\hline & & ST80/ST135 & -28.0 & 0.438 \\
\hline & & ST80/ST80+ST135 & -30.0 & 0.344 \\
\hline \multirow{5}{*}{ Sample 3} & \multirow{5}{*}{ ST80/ST80+ST40 } & ST80/ST80 & $42.2^{*}$ & 0.003 \\
\hline & & ST80/ST150 & 3.8 & 1.000 \\
\hline & & ST80/ST150+ST40 & 8.4 & 0.978 \\
\hline & & ST80/ST135 & -24.2 & 0.544 \\
\hline & & ST80/ST80+ST135 & -26.2 & 0.435 \\
\hline \multirow{5}{*}{ Sample 4} & \multirow{5}{*}{ ST80/ST150 +ST40 } & ST80/ST80 & $33.8^{*}$ & 0.006 \\
\hline & & ST80/ST150 & -4.6 & 1.000 \\
\hline & & ST80/ST80+ST40 & -8.4 & 0.978 \\
\hline & & \begin{tabular}{|l} 
ST80/ST135 \\
\end{tabular} & -32.6 & 0.224 \\
\hline & & ST80/ST80+ST135 & -34.6 & 0.172 \\
\hline \multirow{5}{*}{ Sample 5} & \multirow{5}{*}{ ST80/ST135 } & ST80/ST80 & $66.4^{*}$ & 0.016 \\
\hline & & ST80/ST150 & 28.0 & 0.438 \\
\hline & & ST80/ST80+ST40 & 24.2 & 0.544 \\
\hline & & ST80/ST150+ST40 & 32.6 & 0.224 \\
\hline & & ST80/ST80+ST135 & -2.0 & 1.000 \\
\hline \multirow{5}{*}{ Sample 6} & \multirow{5}{*}{ ST80/ST80+ST135 } & ST80/ST80 & $68.4^{*}$ & 0.013 \\
\hline & & \begin{tabular}{|l|} 
ST80/ST150 \\
\end{tabular} & 30.0 & 0.344 \\
\hline & & ST80/ST80+ST40 & 26.2 & 0.435 \\
\hline & & ST80/ST150+ST40 & 34.6 & 0.172 \\
\hline & & ST80/ST135 & 2.0 & 1.000 \\
\hline
\end{tabular}

\section{CONCLUSIONS}

Sewing technology is the mostly preferred method for joining garment pieces. In case of manufacturing waterproof garments, sewing has disadvantage of causing needle damages due to needle along the seam line. The needle holes cause leakage of water. To prevent this problem, seam sealing is used to cover the seam area. In welding and bonding techniques, waterproof seams are obtained as these methods do not cause needle damage. In this study, experiments have been carried out on the availability of fusible yarns to improve the waterproofness properties of the seams. The difference of this method is its getting waterproof seams by covering just the needle damages with fusible sewing threads instead of the seam area. Initial results of the current research show that fusible sewing threads can help to cover the needle damages. However, there is no sewing thread that is produced for this purpose. Unbalanced seam is the problem that should be considered and be solved in this method. For this, the fusible sewing threads, which have different melting points and structure that enables to cover the damages more effectively, can be designed in the further studies. It is expected that the use of a fusible sewing thread, which will be designed for using for improving waterproofness of seams and will be used in both lower and upper thread, will further improve the waterproofness property and will prevent the unbalanced seam.

\section{REFERENCES}

1. Jeong, W.Y., Kook, S. Seam Characteristics of Breathable Waterproof Fabrics with Various Finishing Methods Fibers and Polymers 4 (2) 2003: pp. 71-76. https://doi.org/10.1007/BF02875440

2. Shi, H., Wang, J., Chen, X., Luo, S., Zhang, L. Research on the Seam Performance of Waterproof Clothing Based on Continuous Ultrasonic Welding Technology International Journal of Clothing Science and Technology 28 (2) 2016: pp. $171-190$. https://doi.org/10.1108/IJCST-03-2015-0036

3. Jeong, W.Y., Kook, S. Mechanical Properties of Breathable Waterproof Fabrics with Seaming and Sealing Processes Fibers and Polymers 5 (4) 2004: pp. 316-320. https://doi.org/10.1007/BF02875531

4. Jana, P. Assembling technologies for functional garmentsAn Overview Indian Journal of Fiber and Textile Research 36 (4) 2011: pp. 380-387.

5. Shishoo, R. The global textile and clothing industry, Woodhead Publishing Series in Textiles, 2012.

6. Hayes, S., Mcloughlin, J. The Sewing of Textiles, Joining textiles Principles and applications, The Textile Institute and Woodhead Publishing, 2013. 
7. Seram, N., Cabon, D. Investigating the Possibility of Constructing Different Seam Types for Clothing Using Ultrasonic International Journal of Clothing Science and Technology 25 (2) 2013: pp. 90-98. https://doi.org/10.1108/09556221311298583

8. Jones, I., Patil, A. Laser seaming of fabrics, Joining textiles Principles and applications, The Textile Institute and Woodhead Publishing, 2013.

9. Jakubčionienė, $\check{Z}, \quad$ Masteikaitè, V., Kleveckas, T., Jakubčionis, M., Kelesova, U. Investigation of the Strength of Textile Bonded Seams Materials Science (Medžiagotyra) 18(2) 2012: pp. 172-176. https://doi.org/10.5755/j01.ms.18.2.1922

10. Grineviciute, D., $\quad$ Valaseviciute, L., $\quad$ Narviliene, V., Dubinskaite, K., Abelkiene, R. Investigation of Sealed Seams Properties of Moisture Barrier Layer in Firefighters Clothing Materials Science (Medžiagotyra) $20(2)$ 2014: pp. $198-204$. https://doi.org/10.5755/j01.ms.20.2.3396

11. Vlad, L., Stan, M., Buhai, C. The Optimization of the Assemblies Applied to Products Made of Waterproof Fabrics Tekstil ve Konfeksiyon 23 (2) 2013: pp. 273-279.

12. Korycki, R., Szafranska, H. Thickness Optimisation of Sealed Seams in Respect of Insulating Properties Fibres \& Textiles in Eastern Europe 252 (122) 2017: pp. 68-75. https://doi.org/10.5604/12303666.1228185

13. Jevsnik, S.,

Eryuruk, S.H.,

Kalaoglu, F., Karaguzel Kayaoglu, B., Komarkova, P., Golombikova, V., Stjepanovic, Z. Seam Properties of Ultrasonic Welded Multilayered Textile Material Journal of Industrial Textiles 46 (5) 2017: pp. 1193-1211. https://doi.org/10.1177/1528083715613632

14. Radhakrishnan, S., Kumari, D. Seams for Protective Clothing-An Overview World Journal of Textile Engineering and Technology 3 2017: pp. 16-23.

15. Mamanuya, Y., Iurzhenko, M. Copolyamides-Versatile Engineering Polymers, Advances in Progressive Thermoplastic and Thermosetting Polymers, Perspectives and Applications. Technopress; 2012.

16. EMS -Grilltech In: GRILON®- Fusible bonding yarns; https://districo.com/page-gb/bondingyarn.html [retrieved $: 02 / 11 / 2019$

17. Stylios, G.K. The Mechanics of Stitching, Joining Textiles Principles and applications The Textile Institute and Woodhead Publishing, 2013.

18. Mukhopadhyay, A., Midha, V.K. The quality and performance of sewn seams Joining Textiles Principles and applications The Textile Institute and Woodhead Publishing, 2013.

(C) Mesegul et al. 2020 Open Access This article is distributed under the terms of the Creative Commons Attribution 4.0 International License (http://creativecommons.org/licenses/by/4.0/), which permits unrestricted use, distribution, and reproduction in any medium, provided you give appropriate credit to the original author(s) and the source, provide a link to the Creative Commons license, and indicate if changes were made. 